\title{
REFERENCES
}

Allen, K.R. (1938). Some observations on the biology of the trout (Salmo trutta) in Windermere. Journal of Animal Ecology 7: 333-349.

Choudhary, D.K., P.S. Choudhary and Chhatbar (1975). A preliminary study of some morphometric characters of Hilsa Sinensis (L.). Association, CIFA, Souvenir 1: 32-34.

Devi, T.N., F. Khumar and M.S. Siddiqui (1991). Observations on the morphometric characters of the Catfish, Rita rita (Hamilton) from the River Yamuna in North India. Journal of Inland Fisheries Society of India 23(1): 52-58.

Hamza, A.E. (1980). Studies on certain aspects on biology and reproduction of genus Notopterus. Ph.D. Thesis, Culcutta University, Calcutta, India (Unpublished).

Kalita, K. and R.K. Rath (1996). Length-weight relationship of male Notopterus notopterus (Pallas). Journal of Environment and Ecology 14(4): 983-984.

Kiran, B.R. (2002). Studies on the biology of Chela untrahi of Bhadra Reservoir. Ph.D. Thesis, Kuvempu University, India (Unpublished).

LeCren, E.D. (1951). The length-weight relationship and seasonal cycle in gonad weight and condition in the Perch (Perca fluviatilis). Journal of Animal Ecology 20: 210-219.

Martin, W.R. (1949). The mechanics of environmental control of body form in fishes. Toronto University of Biological Studies 58: 1-91.

Parameswaran, S. and M. Sinha (1966). Observation on the biology of the featherback Notopterus notopterus (Pallas). Indian Journal of Fisheries 13: 232-250.

Pauly, D. (1983). Some simple methods for the assessment of tropical fish stocks. FAO Fisheries Technical Paper 234: 1-52.

Sarkar, S.K., C. Medda, S. Ganguly and T.K. Basu (1999). Lengthweight relationship and relative condition of bundh and hatchery bred Labeo rohita (Hamilton) during the early period of development. In: de Silva, S.S (editor). Proceedings of the Asian Fisheries Society, Manila, Phillippines. Asian Fisheries Science 12: 289-296.

Sivakami, S. (1987). Length-weight relationship and relative condition in Ompok bimaculatus (Bloch) from Bhavanisagar Reservoir (Tamil Nadu). Indian Journal of Fisheries 34: 136-140.

Sunil, M.S. (2000). Length-weight relationship in Rasbora daniconius (Ham.) from Achancoil River, Pathanamthitta, Kerala, India. Indian Journal of Fisheries 47(3): 271-274.

\section{NESTING OF BLACK IBIS (PSEUDIBIS PAPILLIOSA) IN THAR DESERT OF RAJASTHAN}

\section{Sumit Dookia}

Desert Regional Station, Zoological Survey of India, Jhalamand, Pali Road, Jodhpur, Rajasthan 342005, India.

During several visits to the Thar Desert of Rajasthan, I saw six nests of Black Ibis (Pseudibis papillosa), out of which three nests were reported on a big Pipal (Ficus religiosa) tree in Mukam Village of Bikaner District. Two nests were seen on Pipal tree in Godra villages of Nagpur District and a single nest was located in Rajasthan Agriculture University Campus, Beechwal, Bikaner, again on a Pipal tree.

All nests were present for quite a long time and the local people claimed that the birds use the same tree for nesting every year. Previously, there were no reports of any nesting from this region. Interestingly I observed all nesting trees to be Ficus religiosa. Nair and Vyas (2003) reported its nesting on Ficus bengalensis. Information on the selection of trees especially Ficus for nesting by these birds is not known.

Ali and Ripley (1978) reported that the Black Ibis breed in northern India, later in Gujarat, the Deccan and in the south. Nair and Vyas (2003) reported a nesting pair in Udupuria Village of Kota District. The localities where I observed nesting are quite far from Kota. All new nesting sites are in the Thar Desert of Rajasthan, hence noteworthy.

\section{REFERENCES}

Ali, S. and S.D. Ripley (1978). Handbook of the birds of India and Pakistan. $2^{\text {nd }}$ edition Vol. I. Divers to Hawks. Oxford University Press, London.

Nair, A. and R. Vyas (2003). Nesting record of Black Ibis Pseudibis papilliosa in Kota District, Rajasthan. Zoos' Print Journal 18(3): 1050.

\section{ACKNOWLEDGEMENTS}

I would like to thank Dr. Q.H. Baqri, Officer-in-Charge, Desert Regional Station, Zoological Survey of India for providing financial support, and facilities to conduct the survey works. 